\title{
Meme Fame
}

\author{
Af Lars Konzack
}

\begin{abstract}
Artiklen beskriver og analyserer de nye former for berømmelse, internettet har skabt og udviklet. Den satter fokus på mennesker, der alene har opnået berømmelse gennem informationsspredning og videndeling på internettet - internet-mem. Hvad er et internet-mem? spørger artiklen. Den gennemgår litteraturen om dette fcenomen og scetter derefter med bestemmelserne som grundlag analytisk fokus på en rakke cases, der illustrerer det.
\end{abstract}

\section{Indledning}

"In the future, everyone will be world-famous for 15 minutes," skulle Andy Warhol have skrevet i programmet til sin udstilling på Moderna Museet i Stockholm I 1968. Det er et godt billede på tiden dengang i det tyvende århundrede, hvor berømmelse kunne afsættes i tidsintervaller i radio og tv. Dette giver ikke helt samme mening, når vi taler om Internettet som medie. Her bliver det mere uklart, hvornår man er berømt, og hvor meget tid, der bliver afsat til det. For tiden til at se et bestemt klip bliver ikke bestemt af en central redaktion, men af brugerne selv. De kan vælge at se og gense mange gange. Ikke nok med det, de kan være med til at udvælge, hvad der skal ligge som grundlag for berømmelse. Hver gang en bruger er med til at dele et videoklip, et billede eller en tekst, kan de være med til at være en del af en større bevægelse eller sætte en bevægelse i gang. For at forstå, hvordan den form for berømmelse foregår, skal vi ikke tænke på det som et center, der iværksætter en strategisk plan for berømmelse, men snarere de mønstre hvorved fiskestimer eller fugleflokke bevæger sig.

Jeg vil i det følgende undersøge cases, hvor berømmelsen ikke udspringer af andet, end at vedkommende er blevet kendt for at få sit udseende delt og spredt på internettet gennem et såkaldt internet-mem. Der findes selvfølgelig mennesker, der i forvejen er kendisser, der bliver genstand for et eller flere internet-memer, men de har ingen interesse i denne sammenhæng. Fokus er udelukkende på mennesker,

Lars Konzack, associate professor, The Royal School of Library and Information Science, University of Copenhagen konzack@hum.ku.dk 
der alene har opnået berømmelse gennem informationsspredning og videndeling på internettet. Derfor har jeg eksempelvis fravalgt Antoine Dodson med internet-memet Bed Intruder, Sweet Brown med Aint Nobody Got Time for That og Charles Ramsey med Dead Giveaway, da det $i$ alle de tre tilfælde er begyndt med et tv-klip, om end deres egentlige berømmelse udspringer fra Nettets brug af disse tv-klip.

\section{Internet-mem}

For at forstå meme fame er det afgørende at begribe begrebet internet-mem. Begrebet mem (eng. meme) blev introduceret af Richard Dawkins i 1976 med udgivelsen af bogen The Selfish Gene (Shifman, 2014). Det er en ganske kontroversiel teori, hvor han sammenligner kulturelle mønstre med biologiske entiteter. Mindstedelen en overfør biologisk entitet er et gen, og tilsvarende er mindstedelen af et kulturelt mønster at opfatte som et mem, hvis man altså skal tro Richard Dawkins, der anser memer (og dermed kulturen) som en slags parasit på den menneskelige biologi. Et mem er kendetegnet ved, at det bliver reproduceret, og dets succes afhænger af troskab, formeringsevne og levetid. Jo, flere der er tro overfor memet, jo lettere det er at reproducere, og jo længere levetid det har, desto større succes får memet $\mathrm{i}$ udbredelse. I et sådant biologisk perspektiv vil varianter, de såkaldte mash-ups, baseret på det samme mem blive opfattet som mutationer.

Selvom ordet mem stammer fra Richard Dawkins biologisme, har begrebet internet-mem i dag kun overfladisk forbindelse til denne oprindelse. Fælles er, at det stadig kan reproduceres, spredes viralt og har en levetid, men det er normalt, at et internet-mem kommer i mange forskellige varianter - eller mutationer, om man vil. Henry Jenkins, Sam Ford og Joshua Green advarer mod at gøre brug af biologiske metaforer, fordi den slags metaforer kan forvirre folk til at tro, at der rent faktisk er tale om en slags biologisk liv. Det ligger nemlig besnærende lige for at opfatte de biologiske metaforer som en sand naturvidenskabelig forklaring, selvom det blot er et billedligt perspektiv, og det kan skabe myter. I de bedste tilfælde er disse myter spændende og kan bruges kunstnerisk i fiktion til at udvide en ellers begrænset forståelsesramme, men i de værste tilfælde er myterne bedrageriske illusioner og livsløgn. I stedet for det biologiske perspektiv foreslår de et medieperspektiv, hvor de ser internettet som et spredningsmedie (Jenkins, Ford \& Green, 2013).

Med et sådant medieperspektiv bliver udfordringen at skabe en humanistisk forklaring og et alternativ til den biologiske myte. Her kan begrebet tema med fordel anvendes. Et tema er i æstetikken et genkendeligt tegn eller mønster, og disse tegn eller mønstre forbliver genkendelige på trods af, at de undergår forandringer. Jeg definerer følgeligt et internet-mem som et tema, der spredes via internettet. Temaet undergår ofte mange variationer (mash-ups) og består af lyd, billede, filmklip, spil eller skreven tekst - gerne som en kombination af to eller flere modaliteter. Ydermere kan temaet være forbundet til en enkelt af disse modaliteter, men behøver det ikke og kan under alle omstændigheder omdannes til nye typer modaliteter.

\section{Berømmelse}

Som vi allerede har antydet, så er berømmelse på internettet ikke nødvendigvis det samme som berømmelse i de gamle massemedier. Hvor berømmelse i de gamle massemedier nærmest krævede stort set alles opmærksomhed, langt hen ad vejen kunne planlægges som strategisk kommunikation i mediebranchen, og hvor den kontraktligt forpligtede berømthed gennem selskaber - ofte private - kunne skabe sig en lukrativ karriere og livsgrundlag på et talent, der gav anledning til denne berømmelse, hvad enten dette talent var skønhed, sport, kunstneriske evner, religiøse, filosofiske og politiske holdninger, familierelationer, misundelsesværdig rigdom eller simpelthen evnen til at kende de rigtige mennesker og netværke. Den form for berømmelse kender vi fra Hollywood-stjerner og har fungeret som forskrift for denne berømmelse. I populærkulturen er den form for berømmelse tydeligt skildret i filmen Fame (1980), hvor unge talentfulde mennesker forsøger at skabe sig en karriere som berømtheder.

Berømmelse har dog også en slagside. Berømte mennesker får ikke kun vist deres positive sider, men også deres skyggesider. De gamle massemedier svælger i skilsmisser, alkohol- og narkomisbrug og personlig fornedrelse. Når berømmelsen har sat en kendis op på en piedestal, er det mindst en lige så god historie hvis ikke bedre at vælte vedkommende ned fra piedestalen. Dette skaber en særlig gruppe af berygtede berømtheder, der var berømte for deres 
talent for år tilbage, men nu lider i skam under offentlighedens søgelys.

Berømmelse baseret på internet-memer følger ikke Hollywoods forskrift. Den får ikke nødvendigvis alles opmærksomhed. Den kan ikke i samme grad planlægges ved hjælp af strategisk kommunikation, da den baserer sig på tilfældigheder. Berømthederne har ingen kontraktlig forpligtelse til selskaber eller andre organisationer, og det har vist sig svært at leve af den berømmelse. Snarere end at udtrykke et særligt talent, så viser internet-memer gerne almindelige mennesker i parodiske situationer. Det betyder også, at berømtheder baseret på internet-memer føler sig snarere skamfuldt berygtede end som feterede stjerner. Dette billede er dog ikke helt entydigt, som vi skal se.

\section{Internet-memers virkemidler}

For at begribe, hvordan internet-memer skaber berømmelse, må vi komme nærmere ind på, hvordan internet-memers virkemidler fungerer. Vi har allerede etableret, at et internet-mem fungerer som et tema, der kan fremkomme i forskellige variationer. Colin Stryker beskriver et internet-mem fra fødsels til død (Stryker, 2011). Fødslen er, at der bliver produceret et billede, en video, en tekst eller lignende. Dette bliver så opdaget og spreder sig via e-mails, hjemmesider og blogs. I begyndelsen er det mest undergrundshjemmesider, men efterhånden bliver det mere kommercielle websteder, indtil det bliver mainstream i de gamle medier. I det øjeblik det bliver mainstream er det muligt at kommercialisere internet-memet og skabe en forretning på det. Men det er også netop det tidspunkt, hvor internet-memet dør ud, fordi interessen for det samtidig forsvinder. Populært kan man sige, at et internet-mem er dødt, når det er blevet vist på tv. Det er modsat, hvad man måske skulle tro, når det får de 'femten minutters' berømmelse, at det ikke er interessant længere.

Michele Knobel og Colin Lankshear har analyseret en internet-memer og nået frem til, at et typisk internet-mem gerne indeholder en eller flere af følgende fire fælles træk: 1) humor, 2) rig intertekstualitet, 3) unormal sammenstilling og 4) afvigelse fra det normale (Knobel \& Lankshear, 2007). Ofte vil den rige interkstualitet, de unormale sammenstillinger og afvigelserne fra det normale resultere $\mathrm{i}$, at der opstår et humoristisk udtryk. Ifølge Limor Shifman gør seks fælles sig gældende: 1) almindelige mennesker, 2) fejlagtig maskulinitet, 3) humor, 4) simplicitet, 5) repetitivitet og 6) finurligt indhold (Shifman, 2014). Michele Knobel, Colin Lankshear og Limor Shifman er alle enige om, at humor er et fælles træk for internet-memer. Men derudover er der egentlig ikke megen enighed, om end man kan forestille sig, at unormale sammenstillinger og afvigelser fra det normale kan have noget at gøre med finurligt indhold. Men omvendt kan man godt forestille sig finurligt indhold uden unormale sammenstillinger og afvigelser fra det normale. Hvis vi tænker det sammen som en helhed, vil der derfor være overlap, men det gælder jo også humor, som vi allerede har set. Givet, at der allerede er overlap i de fælles træk, giver det god mening, at tænke de fælles træk sammen, således får vi i alt ni fælles træk for internet-memer 1) humor, 2) rig intertekstualitet, 3) unormal sammenstilling, 4) afvigelse fra det normale, 5) almindelige mennesker, 6) fejlagtig maskulinitet, 7) simplicitet, 8) repetitivitet og 9) finurligt indhold. Det er ikke således, at alle internetmemer vil besidde alle ni træk, men vi må forvente, at mange af de fælles træk vil være til stede, og det giver en mulighed udpege disse træk.

\section{Star Wars Kid}

I 2002 optog Ghyslain Raza, en overvægtig 15årig dreng fra Canada, sig selv på video, mens han foretog fægteøvelser som en anden Jedi-ridder fra Stjernekrigen - dog med en golfbold-retriever. (Moore, Guntupalli, \& Lee, 2010). Den originale video er knap to minutter lang og har dermed en passende længde til at folk gider se den færdig. Videoen i sig spredte sig viralt på Nettet, men det der gjorde den til et internet-mem var, at der blev lavet parodier, og den indgik i mange andre sammenhænge. Ghyslain Raza havde ikke nogen intention om at blive kendt. Videoen blev fundet i hans kælder af nogle klassekammerater, der lavede en digital kopi og uploadede den til Nettet med titlen Jackass_starwars_funny. wmv.

Denne video blev spredt, men ikke nok med det, dens tema med stjernekrigen nærede kreativiteten, og der blev lavet mange parodier i form af billeder og videoer. Den 22. april 2003 udsendte spiludvikler Bryan Dube en redigeret video, hvor han ved hjælp af CGI fik Ghyzlains golfbol-retriever til at ligne et lyssværd komplet med lyd- og lyseffekter og intro i stil med den fra Stjernekrigen. Den blev uploadet 
under titlen Star_Wars_Kid.wmv. Det var samtidig med, at den anden bølge af Stjernekrigsfilm gik over lærredet, så rigtig mange kunne forholde sig til det, og Ghyslain Raza så unægtelig latterlig ud som han stod og kæmpede ud i luften. Nu til den rigtige Stjernekrigsmusik.

Hvis vi skal beskrive den ud fra vores kriterier for et internet-mem, så har den humor, rig intertekstualitet til Stjernekrigen, en unormal sammenstilling mellem en Jedi-ridder og en lidt klodset, overvægtig knægt, afvigelse fra det normale, et almindeligt menneske, der udviser fejlagtig maskulinitet, simpelt og repetitivt. Den har med andre ord det hele, der skal til.

Men det er ikke sjovt at blive berømt eller nok snarere berygtet på den måde. Ghyslain Raza blev udsat for mobning på skolen og internet-mobning, og han har senere beskrevet det som en mørk periode i sit liv (Christensen, 2011). Han blev inviteret til alle diverse kendte tv-shows, men afslog, fordi han ikke havde lyst til at blive udstillet som en cirkusklovn. Alligevel nåede det længere ud i nørdkulturen, således har klippet Star Wars Kid været parodieret i South Park, Family Guy, American Dad og i Weird Al" Yankovics sang White and Nerdy.

Det lykkedes ikke for Ghyslain Raza at vende denne situation til noget positivt. Familien indgik forlig udenfor retten med drengenes forældre. Men ud over det, var der ikke nogen erfaring, som Ghyslain Raza kunne bygge på, og han kunne ikke håndtere at blive mobbet på den måde. Ghyslain Raza forblev et offer for internet-mobning ude af stand til at gøre noget andet end at håbe, det eventuelt drev over.

\section{Charlie bed mig}

"Charlie Bit Me" er en engelsk viral YouTube-video fra maj 2007, hvor den treårige storebror Harry putter en finger ind i munden på sin etårige lillebror Charlie, som bider den. Storebroren beklager sig, prøver igen og bliver derefter ved med at beklage sig over, at Charlie bed hans finger. Til sidst griner lillebroren (Shifman, An Anatomy of a YouTube Meme, 2012). Videoen varer knap et minut og blev delt på Nettet, sandsynligvis fordi den var så sød.

De to drenge blev med denne video, som deres far havde uploadet, pludselig en slags internet-kendisser, børneberømtheder. Det skyldes ikke mindst, at det gik fra at være en viral video til at antage form af et mem, hvor der kom flere varianter over dette tema, hvor folk parodierede Charlie Bit My finger.

Med over 700 millioner views, en af de mest sete YouTube-videoer, blev opmærksomheden rettet mod vendingen Charlie Bit My Finger, og snart kom det til at være på alskens merchandise fra januar 2008 kopper til T-shirts. Det samlet set har givet familien en indtægt på over tre million kroner. Faderen Howard Davies-Car har gjort opmærksom på, at familien ikke havde til hensigt at profitere på opmærksomheden, men da andre begyndte at tjene penge på opmærksomheden, indgik de en aftale med firmaet Viral-Spiral om at sælge merchandise.

Som man kan se ud af dette eksempel, lykkedes det for familien Davies-Car i modsætning til Ghyslain Raza at få noget positivt ud af denne berømmelse. Men forløbet var også meget anderledes. De havde selv valgt at lægge videoen op. De blev overraskede over den voldsomme modtagelse, men formåede at bruge den positivt til at omsætte den til en uventet indkomst. Det var som at vinde i lotteriet, at netop denne video blandt millioner af andre YouTube-videor lige netop var denne her, der faldt folks smag.

\section{Boxxy}

"FOAR 4DD1 FRUM BOXXY" og "FOAR ANT FRUM BOXXY" er to YouTube-videoer, der blev uploadet til YouTube-kanalen boxxybabee i januar 2009. Bag dæknavnet Boxxy var den dengang 16-årige Catherine Wayne fra Californien. Siden 2006, kun fjorten år gammel, gik hun under et andet dæknavn nemlig MoldyLunchbox fra internet-webstedet Gaia Online - et anime-inspireret online forum med chat og spil. Videoerne viser Boxxy, der fortæller på en spontan begejstret og charmerende nuttet måde, hvad der umiddelbart falder hende ind. For at forstå hvorfor lige netop denne video blev til et internet-mem, bør man kende til begrebet kawaii, et japansk ord, der betyder nuttet, hvilket er en grundbestanddel i anime og manga. Netop anime- og mangafans holdt til på 4chan, hvor de delte søde, sjove og chokerende billeder, hvoraf mange blev til internet-memer. 4chan har siden sin begyndelse i oktober 2003 været storproducent af internet-memer (Stryker, 2011).

Videoerne blev delt på 4chan og skabte øjeblikkeligt et væld af kommentarer og billeder. Hvad der var 
anderledes i forhold til andre memer var det forhold, at 4channers (folk på 4chan) delte sig i to grupper, nemlig der elskede hende og kaldte hende dronning af 4chan, og dem der hadede hende og opfattede hende som den kræftsyge, der ødelagde 4chan. Boxxy var uden at ane det pludselig blevet en kontroversiel person, som 4channers enten elskede eller hadede. Denne Boxxymania endte med, at 4chans server blev lagt ned i et såkaldt DDoS-angreb. Det stoppede dog ikke der, for Boxxy havde opnået status af en nærmest mytisk figur (Liu, 2011).

Catherine 'Boxxy' Wayne blev chikaneret. Billeder af Catherine Wayne blev lagt ud på Nettet. Der blev lavet memer, hvor hun fik halsen skåret over eller havde fået øjnene skåret ud og munden skåret op. Der var også kvinder, der uploadede billeder til 4chan, hvor de på deres bryst havde ksrevet "Kill Boxxy", "Fuck Boxxy" eller "Boxxy Sucks" (Fuchs, 2014). Hendes reaktion var at lave en tredje video, hvor hun svarede sine fans og haters. I videoen "FOAR EVERYWUN FRUM BOXXY" fra januar 2009 svarer hun, at hun ikke bruger stoffer og fortæller hendes version af historien. Derefter gik hun i flyverskjul, indtil november 2010, hvor hun forsøgte at tasker på en eBay-aktion (Stryker, 2011). Videoerne afstedkom en lang række musikalske remixes, der blev til Boxxy-sange, hvoraf et par de mest kendte er "Love and Trolls" (2009) af deepfatfryed og "You See" (2011) af danielson742 - begge uploadet til YouTube.

I forbindelse med Catherine Waynes forsøg på at sælge tasker lancerede hun en ny YouTube-kanal nemlig ANewHopeee, hvorfra hun i januar 2011 relancerede sig selv en lang række nye videoer. I første omgang forsøgte hun sig med at lave sjov, men det virkede ikke. Hvor det i de første videoer havde været den umiddelbare uskyldighed, der havde virket dragende, var magien forsvundet, nu da hun selvbevidst forsøgte at være sjov. I stedet blev det en kanal, hvor hun fortalte om løst og fast. Og med mere end 300.000 faste abonnenter må den siges at være en pæn succes, men interessen for Boxxy er dalende. Catherine Wayne har sidenhen i 2013 og 2014 lagt tre nye videoer op på YouTube-kanalen, hvor hun har klædt sig ud ligesom dengang hun var 16 år, og hvor hun forsøger at tale med samme naivitet, begejstring og nuttethed, men det virker påtaget og mangler den tiltrækning, der var da hun blev udnævnt til dronning.

\section{Rebecca Black}

14 marts 2011 blev musikvideoen "Friday" lanceret. Den blev sunget af den dengang kun 13-årige pige Rebecca Black fra Californien. Sangen handler om en pige, der står op og glæder sig til at feste om fredagen. Teksten var imidlertid så enfoldig og intetsigende, samtidig med at den stereotypt anvendte floskler fra musikvideoer og en forfærdelig tydelig brug af auto-tune, at den nemt kunne være blevet glemt. Der skete det stik modsatte. Den spredte sig som en steppebrand på Nettet og blev den hastigst voksende video på YouTube. Den nåede at blive set over 167 millioner gange, inden den blev fjernet på grund af ophavsretsmæssige problemer 16. juni samme år. Den fik over 3 millioner dislikes - 87 procent af de samlede ratings og blev på den måde den hidtil mest forhadte musikvideo, hvilket fik medierne til at kalde den for den værste musikvideo nogensinde (Gallo, 2011; Williams, 2011). Sangen blev lagt op igen om efteråret, da den værste virak havde lagt sig og er i dag nået op på over 70 millioner afspilninger, hvilket bringer det samlede antal afspilninger op på over 237 millioner. Dog stadig en del under de over to milliarder afspilninger som Gangnam Style (2012) har opnået.

Dette blev fulgt op af internet-memer baseret på strofer fra sangteksten. Især "which seat should I take" blev brugt som en tilbagevendende catchphrase. Der blev produceret spoof-videoer, der gjorde grin med den oprindelige video, og der blev endda skrevet en bog med titlen " Friday - A Rebecca Black Themed Choose-Your-Own-Adventure Book" (2012) af Daniel McCoy, hvor læseren skal træffe valg som i de gode gamle Sværd-og-trolddom-bøger. Men hvor berygtet Rebecca Black end var blevet, så lykkedes det hende at vende det positivt. Allerede første april samme år, få uger efter den voldsomme lancering, kom hun på comedy websitet Funny or Die, hvor hun gjorde grin med sin egen video (Angelo, 2011).

Det lykkedes Rebecca Black, at blive vært på MTV's første online award show, og allerede samme sommer lancerede Katy Perry musikvideoen "Last Friday Night (T.G.I.F.)", hvor Rebecca Black fik en fremtrædende rolle som nabopigen, der afholder den ultimative fest (Mapes, 2011). Tv-serien Glee lavede et cover af sangen (Goldberg, 2011). Derefter blev der lidt stille om Rebecca Black, indtil hun i december 2013 lancerede en ny musikvideo med titlen "Satur- 
day", hvor hun dels gjorde grin med sin første musikvideo, og dels gjorde grin med Miley Cyrus' twerking-musikvideo "We Can't Stop", der var lanceret nogle få måneder i forvejen.

\section{Overly Attached girlfriend}

Den 6. juni 2012 uploadede den dengang næsten 21-årige Laina Morris fra Texas sangen "JB Fanvideo" til YuoTube under dæknavnet wzr0713. Hun havde optaget den med sit webkamera. Den deltog $i$ en konkurrence om lave en musikvideo baseret på Justin Biebers hitsang "Boyfriend" (Zhao, 2012). Lainas video handlede om en pige, der klyngede sig til en fyr hun slet ikke kendte. Med stift stirrende øjne insisterede hun på at være hans kæreste. Den vandt ikke konkurrencen, men til gengæld vandt den manges interesse. Lainas ansigt med de stirrende øjne blev brugt som fast formel, en såkaldt image macro, til at fremstille memet Overly Attached Girlfriend, der handler om en kvinde, der vil gøre hvad som helst for at få fat i og holde fast på sin kæreste.

Allerede den 18 juni 2012 var hun hurtig til at fange og forstå den interesse, der var opstået omkring hendes person, og hun lavede endnu en parodi-video "CRJ Fanvideo" med karakteren Overly Attached Girlfriend - denne gang baseret på den dengang populære sang "Call Me Maybe" af Carly Rae Jepsen. Overly Attached Girlfriend blev den 16. oktober 2012 identificeret som Laina Morris, og hun har brugt det navn lige siden. Laina valgte at bruge sin berømmelse på at samle ind til velgørenhed (Alfonso III , 2012). Det gav respekt, at hun på den måde ikke bare tænkte på sig selv. Men da hun ydermere var i stand til gennem sine videoer at lave sjov med sig selv med den indforståede humor, der ligger i internet-memer, blev hun en darling.

Sidenhen har hun lavet en lang række videoer og er aktivt til stede på de sociale medier. I november 2012 indgik hun en aftale med Samsung (Gianatasio, 2012). Men også de gamle medier har vist interesse. Således var hun Late Night with Jimmy Fallon den 11. marts 2013, og hun har været i stirre-konkurrence med Jessica Alba, hvor hun vandt.

\section{Konklusion}

Hvis vi ser på de forskellige cases, så kan enhver der er lidt heldig eller uheldig alt efter, hvordan man ser på det, gå hen og blive et internet-mem. Ofte vil det være på en måde, hvor man i begyndelsen fremstår som grinagtig og dum for den måbende omverden. Men det kan med en mediebevidst tilgang lykkes at vende denne uventede berømmelse til noget positivt. Det er klart, at hvis man i forvejen søger berømmelse og har det god med berømmelse, bliver det nemmere, end hvis man ikke bryder sig om det. Men det gælder også om at forstå på hvilke præmisser, man er blevet berømt. Det kan være overvældende, men man bliver alligevel hurtigt glemt igen. Men skal man bruge den berømmelse til noget, bør man forstå den humor og den måde internet-memer fungerer på. Det gjorde Ghyslain "Star Wars Kid" Raza ikke, og han følte sig blot forfulgt og mobbet, hvilket han nok også blev. Charlies forældre var i stand til at skabe sig en indtægt på sønnens tosserier. Catherine "Boxxy" Wayne lykkedes det langsomt at skabe sig et overblik over, hvad der foregik og fik det vendt positivt, mens Rebecca Black og især Laina "Overly Attached Girlfriend" Morris meget hurtigt gik ind denne berømmelse og brugte det til at sætte egen dagsorden og bruge det konstruktivt. Det vil nok aldrig være nemt at få den pludselige opmærksomhed, men hvis man forstår internet-kulturen og den mediemagt, der ligger gemt $i$ internet-memer er der et rigt potentiale til at det ikke blot bliver en dårlig oplevelse, men ligefrem et berigende eventyr.

\section{Referencer}

Alfonso III, F (16. oktober 2012). Overly Attached Girlfriend uses her online fame for a good cause. The Daily Dot.

Angelo, M (1. April 2011). Friday Or Die: Rebecca Black Owns Funny Or Die, Uses It To Further Ponder Seat Choice. Business Insider.

Christensen, JR (2011). The Star Wars Kid and the Bedroom Intruder: Panopticon or Subversion? Akademisk Kvarter 03, Fall 2011, s. 135-46.

Fuchs, C (2014). Anonymous: Hacktivism and Contemporary Politics. I D. Trottier, \& C. Fuchs, Social Media, Politics and the State: Protests, Revolutions, Riots, Crime and Policing in the Age of Facebook, Twitter and YouTube (s. 88-108). London: Routledge. 
Gallo, LM (15. Marts 2011). Who is Rebecca Black? And is she really bigger than Japan? Sydney Morning Herald.

Gianatasio, D (15. November 2012). Samsung Gets Overly Attached Girlfriend to Play a Possessive PC. Adweek.

Goldberg, L (9. maj 2011). 'Glee' Cover of Rebecca Black's 'Friday,' Explained. Billboard.

Jenkins, H, Ford, S, \& Green, J (2013). Spreadable Media: Creatingvalue and Meaning in a Networked Culture. New York: New York University.

Knobel, M \& Lankshear, C (2007). Online Memes, Affinities, and Cultural Production. I M. Knobel, \& C. Lankshear, New Literacies Sampler (s. 199-227). New York: Peter Lang Publ.

Liu, S (Spring 2011). The Most Popular Thing You've Probably Never Heard of. Stylus, s. 1-4.

Mapes, J. (13. juni 2011). Katy Perry Parties With Rebecca Black, 'Glee' Cast in 'Last Friday Night' Video. Billboard.
Moore, R, Guntupalli, NT \& Lee, T (July / July - December 2010). Parental Regulation and Online Activities: Examining factors that influence a Youth's potential to become a Victim of Online Harassment. International Journal of Cyber Criminology: Vol 4 Issue $1 \& 2$, s. 685-98.

Shifman, L (2012). An Anatomy of a YouTube Meme. New Media \& Society 14(2), s. 187-203.

Shifman, L (2014). Memes in Digital Culture. Massachusetts: The MIT Press.

Stryker, C (2011). Epic Win for Anonymous: How 4chan's Army Conquered the Web. New York: Overlook Press.

Williams, ME (Mandag. Marts 2011). What's behind the "worst music video ever"? Salon.

Zhao, W (14. juni 2012). Rise Of The Overly Attached Girlfriend. Forbes. 